\title{
Soil foundation and structure interaction effects on the estimating of fundamental period of instrumented buildings
}

HAITEM TORKIA ( $\nabla$ haithemgcvil@yahoo.fr)

Universite Hadj Lakhdar Batna

Maalem Toufik

Universite Batna 2

Lahbari Noureddine

Universite Batna 2

Full paper

Keywords: SFSI, Geotechnical conditions, VN7SH, Soil, Design codes, Period, buildings recorded, Height

Posted Date: June 29th, 2020

DOI: https://doi.org/10.21203/rs.3.rs-37912/v1

License: (c) (i) This work is licensed under a Creative Commons Attribution 4.0 International License.

Read Full License 


\title{
Soil foundation and structure interaction effects on the estimating of fundamental period of instrumented buildings
}

\author{
Torkia Haitem $^{1}$, Maalem Toufik ${ }^{2}$, Lahbari Noureddine ${ }^{3}$ \\ ${ }^{1}$ institute of architecture and urbanism, LAUTr laboratory, University of Batna 1, Algeria \\ ${ }^{2}$ Department of Civil Engineering, Faculty of Technology, University of Batna 2, Algeria \\ ${ }^{3}$ Department of Civil Engineering, Faculty of Technology, University of Batna 2, Algeria \\ ${ }^{1}$ Corresponding author Tel: +213558153397 \\ E-mail address: haithemgcvil@yahoo.fr, haitem.torkia@univ-batna.dz
}

\begin{abstract}
:
The aim of this paper is to propose new expressions for fundamental period of reinforced concrete buildings which take into account soil foundation and structure interaction SFSI effects and its variation of 215 existing buildings located in the USA, Europe and Asia. Diagrams represent empirical relationship between fundamental period-height in most recent research and building codes. No difference was observed in the value of period T as a result of degradation of the soil bearing capacity in these ranges. It is incorrect to present a single equation or a single diagram for different geotechnical conditions. To evaluate SFSI effects, a simplified SFSI modal is described in this work, using on Van nuys building-VN7SH and results are compared with those obtained by different authors. In order to develop simplified equations for estimating fundamental periods of vibration for 03 geomorphological sites, 40 existing buildings recorded over a period of 24 years located in the site of California are utilized, that encompass a wide range of structural and geotechnical conditions. On the other hand,175 more buildings used from Europe and Asia exposed to earthquake actions were examined to evaluate the accuracy of the relationship. A collective examination of the empirical, measured and procedures show that the fundamental period is fonction of to the building overall height $H$ estimated on empirical formulas provided by earthquake design codes used for buildings under SFSI conditions effects under certain circumstances, underestimate the real response of the structures.
\end{abstract}

The results reveal the effects of SFSI due to an earthquake recorded motion on the response of buildings depends mainly on the soil mass amplification, as well as secondary influences from type, shape and inertia of foundation.

Key words: SFSI, Geotechnical conditions, VN7SH, Soil, Design codes, Period, buildings recorded, Height.

\section{Introduction}

The periods of vibration and damping ratios of buildings are important characteristics in determining their seismic behaviour. Local site effects, based on subsurface ground conditions, also have remarkable influence on the level of building damage and on damage distribution during an earthquake. Since the 1985 Michoacán earthquake (México), building damage has been studied analysing the contribution of site response, in particular when resonant phenomena between soil and structure appears. More recent destructive earthquakes (e.g., Northridge, California 1994; Kobe, Japan 1995; Izmit, Turkey 1999 or Chi-Chi, Taiwan 1999; Colima, Mexico 2003; Al Hoceimas, Morroco, 2004) have shown how unconsolidated soil and sediment deposits were responsible for important modifications in ground motion amplitude in a range of periods and how building damage increases when the fundamental vibration period of the building is close to the predominant period of the soil motion [1].

During an earthquake event, the structure interacts with the foundation soil causing it to deform. The soil deformations, in turn, cause the motion of the supports or the interface region of the soil and the structure to be different from than that of the free field ground motion. Such ongoing interactions cause a substantial change in the response of both the structure and the soil. Seismic analysis of a structure considering the soil properties is different from that considering embedded at its base [2]. Therefore, it is particularly important to consider the Soil Foundation Structure Interaction SFSI effects in seismic areas where soil dynamic response can affect the response of structures subjected to seismic excitation Davidovici [3] and AFPS [4], Pitilakis [5], Piro [6], Smith [7], Abdel Raheem [8], Fares [9], Mihailo [10], Todorovska [11] and Haitem [12]. An increase of 78\% was observed by Jayalakshmi [13] and of 70\% according to Kraus [14]. In addition, soft sites receiving massive and rigid structures can change the dynamic characteristics of the response significantly Eurocode [15] and John [16]. This is already mentioned in the works of Khalil with an error of $70 \%$ [17].

Goel and Chopra [18] and [19] carried out the regression analysis of measured data to develop formulas to estimate fundamental periods of the buildings. Database contained a total of 106 Californian buildings including 21 of them with peak ground acceleration PGA higher than $0.15 \mathrm{~g}$. It was noticed that the calculated code periods were shorter than the measured periods from the recorded motions, underestimating the real value of the period to a $100 \%$ error. For buildings up to 36 meters high, the code formulas produced lower-bound values compared to measured period data, on the other hand, the same formulas resulted in $20 \%$ to $30 \%$ shorter periods compared to the measured ones for buildings taller than 36 meters. For many buildings, measured period values were greater than $1.4 \mathrm{~T}$, where $\mathrm{T}$ was described as the fundamental period obtained from the empirical equation.

Celebi (1998) carried out small amplitude tests on five buildings after the LomaPrieta earthquake in 1989. As expected, the first mode periods and damping ratio extracted from strong-motion response records were larger than those associated with ambient 
vibration records [20]. The ratio of these two periods for tested buildings was approximately 20 - 50\%. It was suggested that these differences may have been caused by several factors, such as the nonlinear behavior of the structure, a soil-structure interaction, and an interaction between structural and non-structural elements.

Hong and Hwang (2000) suggested a relationship between height and fundamental period of vibration for Taiwanese RC momentresisting frames [21]. They measured 21 buildings subjected to moderate-intensity earthquakes and found that Taiwanese buildings were stiffer than their Californian counterparts. The results of the Taiwanese study seem to suggest that it is important to develop region-specific and simplified period height formulae based on the design and construction practices of the specific country [22].

Lee and al. (2000) measured fundamental periods on $50 \mathrm{RC}$ buildings, and these results were compared with those obtained by code formulas and also by dynamic analysis [23]. The comparison showed that comparatively large errors are likely to occur when code formulas were used. Lee and al. concluded that none of the code formulas examined in their study are sufficient for estimating the fundamental period of apartment buildings with shear wall system SW dominant systems [24].

Crowley and Pinho (2006) have proposed an empirical relationship between period $\mathrm{T}$ and height $\mathrm{H}$ " $\mathrm{T}=0.1 \mathrm{H}$ " with a view to assess their validity for use in displacement-based structural assessment. This is followed by an extensive analytical study whereby the yield period of vibration of 17 reinforced concrete frames from 5 different European countries, is estimated by means of eight different procedures involving eigenvalue, pushover and nonlinear dynamic analyses. it has been found that European structures built before the introduction of capacity design principles in seismic regulations, tend to feature higher periods of vibration than their modern counterparts [25].

Kwon and Kim (2010) evaluated building period formulas in seismic design code with over 800 apparent building periods from 191 building stations and 67 earthquake events [26]. The evaluation was carried out with the formulas in ASCE 7-05 for steel and RC MRF, SW buildings, braced frames and other structural types. The differences between the periods from code formula and measured periods of low- to-medium rise buildings were relatively high [27].

Elgohary (2013) carried out a parametric study using finite element analysis to study the effect of the major parameters influencing the fundamental period [28]. He concluded that the code's formulae, in most cases, underestimate the fundamental period with a large deviation from finite element results. This large deviation is a result of considering only the effect of frame height and neglecting of remaining major parameters in the codes formulae.

Prakash and Dubey (2015) predicted the fundamental period of vibration of reinforced concrete buildings with moment resisting frames by considering the effect of building base width in both directions and stiffness of the structure [29]. Values of the time period of vibration differ substantially, and the variation comes out to be on higher side than those derived from code base formula,

Recently, many experimental and numerical studies as well as many research projects have been carried out in order to define in a simplified way the fundamental period of Reinforced Concrete buildings, Gallipoli [30], Crowley [31] and Al-Nimry [32]. Particularly, empirical relationships between the height of a building type and its fundamental period of vibration have been sought, as they can be very useful in many applications - Table 1. Simplified expressions are mandatory in large scale applications, where the period of a building (or of a class of buildings) needs to be estimated in assessing the seismic vulnerability at urban scale [33].

The originality of this study consists in showing the importance of inclusion of the SFSI effects : structure "inertia $\mathrm{I}_{\mathrm{Str}}$ and mass $\mathrm{W}_{\mathrm{St}}$ ", foundation "inertia $\mathrm{I}_{\mathrm{F}}$ and mass $\mathrm{W}_{\mathrm{F}}$ " and soil " mass $\mathrm{W}_{\mathrm{s}}$ " on the estimation of fundamental periods $\mathrm{T}$ of existing buildings by present SFSI modal using on Van Nuys 7 story hotel "VN7SH" and are compared with those obtained by Adeli, wave travel times method WTT and measured.

40 existing buildings located in the USA considered to represent low-medium and hight -rise and according to code designed with a wide range of structural and geotechnical conditions, as well as for developing new simplified equations for estimating fundamental periods of vibration for 03 categories of soil which take into account of the SFSI effects - empirical relationship between fundamental period-height with measured periods of vibration during earthquakes for reinforced concrete "RC" buildings type moment resisting frames "RC MRF" and dual wall frame system "RC DWF", the empirical equations were developed through an iterative linear regression analysis from many recorded strong motion data.

128 more buildings used from 5 different European countries "Italy, Slovenia, Hungary, Macedonia and Greece", and 47buildings from Asian country "Iran" exposed to earthquake action were examined to evaluate the accuracy of the relationship. The proposed formulas considering the SFSI effects have a good agreement with those recorded.

\section{Fundamental period equation for buildings by different research and seismic codes}

Since the predicted fundamental period is used to obtain the expected seismic load affecting the structure, a precise estimation of it is important for the safety of the applied procedure in the design steps and consequently in the future performance of the structure after it is constructed. The fundamental period of vibration required for the simplified design of RC buildings has been calculated for many years using a simplified formula relating the period to the height of the building [36]. 
Traditionally, the simplified formula adopted in the technical literature [37] relates the period of vibration to the height $\mathrm{H}$ of the building in the following form:

$$
\mathrm{T}=\alpha \cdot \mathrm{H}^{\beta}
$$

where $\alpha$ and $\beta$ are empirical coefficients depending on the structural type. Eq (1) is obtained numerically by the Rayleigh method and as indicated by Chopra (1995). A brief overview of simplified empirical equations for estimating fundamental periods of vibration $\mathrm{T}$ by different seismic codes are presented in the Table 2.

We observe:

- The equation type $\mathrm{T}=\alpha \mathrm{H}^{\beta}$ for the estimation of the value of the vibration period of building is still the most common and simple way to express the variation of period for the different building types do not consider the SFSI effects, and has been adopted in many countries in Europe, Asia, America and Latin-America to represent their buildings.

- Diagrams representing empirical relationship between fundamental period-height in most recent research and national building codes. No difference was observed in the value of period $\mathrm{T}$ as a result of degradation of the soil bearing capacity in this ranges.

- It is illogical to present a single equation or a single diagram for different geotechnical conditions.

Goel and Chopra (1997 and 2000) collected data measured from eight Californian earthquakes, from 1971 (San Fernando earthquake) until 1994 (Northridge earthquake) and showed that it generally underestimates the periods of vibration measured from 27 RC frames, especially those above sixteen stories. Therefore, different formulas propose from resulting semiempirical analysis, with the best-fit plus 1 standard deviation recommended for displacement-based assessment, whilst the best-fit minus 1 standard deviation recommended for conservative force-based design [34]:

$$
\begin{aligned}
& \mathrm{T}_{\text {Uper limit }}=0.067 \mathrm{H}^{0.9} \\
& \mathrm{~T}_{\text {Lower limit }}=0.0466 \mathrm{H}^{0.9}
\end{aligned}
$$

where $\mathrm{H}$ is the height of the structure [m]. The latter period-height formula has been included in ASCE7-05 (2006).

\section{Description of SFSI model and Formulation of periods}

To illustrate, the effect of various factors depends on : structure "height, number of stories, inertia $\mathrm{I}_{\mathrm{Str}}, \mathrm{mass}_{\mathrm{S}} \mathrm{W}_{\mathrm{St}}$ and damping ratio of structure $\varphi$ ", Foundation "inertia $\mathrm{I}_{\mathrm{F}}$ and mass $\mathrm{W}_{\mathrm{F}}$ " and Soil " shear wave velocity $\mathrm{V}_{\mathrm{S}}$, mass $\mathrm{W}_{\mathrm{s}}$ and damping ratio of soil", influencing in the effects on the estimation of fundamental periods, we consider the proposed model for the SFSI effects in Fig. 1. The SFSI model suggested shear, bending deformation of the super structure, and relative stiffness between the soil and foundation. From the results observed in the preceding works Haitem (2015) [38], It is clearly indicated that the equations for the fundamental period of vibration considering the SFSI effect will be as following:

$$
T^{*}=\sqrt{m r T_{S}^{2}+m \lambda T_{b}^{2}}
$$

$\mathrm{T}^{*}$ : Fundamental period taking into account SFSI effects, $\mathrm{T}_{\mathrm{s}}, \mathrm{T}_{\mathrm{b}}$ : Shear fundamental and flexural fundamental period without Soil Structure Interaction effects, $r$ : Ratio of shear stiffness, m: Ratio of unit mass of building and $\lambda$ : Ratio of the moment of inertia with and without SFSI given by Haitem [38].

According to Schuller (1977), the shear mode represents $80 \%$ of the value of the period without SFSI and $20 \%$ in the flexural mode, therefore the simplified equation for the final evaluation of the fundamental period taking into account the properties of structure, soil, and foundation becomes:

$$
\frac{T^{*}}{T}=\sqrt{m(0.64 r+0.04 \lambda)}
$$

With T: fundamental period calculated by the empirical formulas presented in the most codes without SFSI.

Statistical analysis of numerical simulations results on a wide range of rigid, semi rigid and flexible frames are obtained in the previous work [38]. It resulted in the determination of the values $\mathrm{m}, \mathrm{r}$ and $\lambda$ coefficients. It also helped to formulate simplified expressions for the evaluation of the fundamental period.

From the point of view of Table 2, we notice a constant relationship between simplified equations for estimating fundamental periods of vibration for buildings with moment resisting frame $\mathrm{T}_{\mathrm{RC} \text { MRF }}$ and other with shear wall system $\mathrm{T}_{\mathrm{RC}} \mathrm{sw}$.

$$
\mathrm{T}_{\mathrm{RC} \mathrm{SW}} / \mathrm{T}_{\mathrm{RCMRF}} \approx 0.667
$$


For 03 Geomorphological zones defined in Table 3 and according to this ratio, new expressions for fundamental period of building type reinforced concrete with moment resisting frames and dual wall frame system which take into account soil foundation and structure interaction SFSI effects are represented in the form of flowchart in Fig.2, presented in their simple and easy way to the different users. In all sites, the simplified expressions fall between:

- $\quad 0.832 \mathrm{~T}$ and $1.341 \mathrm{~T}$ for buildings for buildings with dual wall frame system RC DWF

- $0.998 \mathrm{~T}$ and $1.609 \mathrm{~T}$ for buildings for buildings with moment resisting frames RC MRF

According to previous research to Goel and Chopra, the periods of most buildings fall between the curves for 1.2T and 1.4T, indicating that the code limits on the period calculated from rational analysis may be reasonable for high-seismic regions. Data on measured periods of buildings in regions of low seismicity are needed to evaluate the much higher values of $1.7 \mathrm{~T}$ permitted in NEHRP-94. These limits are important and complementary and being a way to calibrate the new expressions for fundamental period of building.

The suggested relationship between height and fundamental period of vibration considering the potentialities of the soil foundation and structure interaction SFSI effects, 215 existing buildings located in the USA, Europe and Asia are utilized.

\section{Data analysis}

To evaluate the SFSI effects, two ranges of dynamic measurements are used in this study on different soils as shear wave velocity. First range is Van Nuys 7 story hotel VN7SH and second range is application of 214 buildings in USA, Europe and Asia.

\subsection{Case study of Buildings in USA}

\subsubsection{Van Nuys 7 story hotel VN7SH - Geomorphological zone II}

The building analysed is a seven-story reinforced concrete hotel structure, located in central San Fernando Valley of the Los Angeles metropolitan area at $34.221^{\circ} \mathrm{N}$ and $118.471^{\circ} \mathrm{W}$, northwest from downtown Los Angeles [39] (Todorovska et al. 2001). Fig. 3 shows: (A) a plan view of a typical floor, (B) the foundation layout, (C) VN7SH - North-Est elevation, and (D) a side view of the building [40].

Located on undifferentiated Holocene alluvium, average shear wave velocity of $300 \mathrm{~m} / \mathrm{s}$ at the top (30 m) of soil [41]. 12 Strong's motions were recorded over a period of 24 years in the VN7SH building. In chronological order, all these records are listed by Trifunac and al. (1999) [42] and Porter and al. (2004) [43]. The main structural characteristics used for analysis are presented in Table 4

\subsubsection{Buildings in California - Geomorphological zone II}

The database includes observed period values for $40 \mathrm{RC}$ buildings in transverse and longitudinal directions, measured during the 1971 San Fernando and subsequent earthquakes. Some strong motion records obtained during the Loma Prieta and Northridge earthquakes [44] and [45].

\subsection{Case study of Buildings in Europe}

\subsubsection{Buildings in Italy, Slovenia, Hungary and Macedonia - Geomorphological zone III}

108 buildings of Europe exposed to earthquake action, the vast majority of which were designed and built between 1930 and 1980 , Most of the buildings are frame structures, with a limited number of shear wall buildings [46].

\subsubsection{Buildings in Greece - Geomorphological zone I}

20 structures in greece are considered to represent low-rise to medium-rise about up to $30.0 \mathrm{~m}$ in elevation, typical beam column RC space frame buildings in combination with shear walls [47].

\subsection{Case study of Buildings in Asia}

\subsubsection{Buildings in Iran - Geomorphological zone III}

The database consists of $30 \mathrm{RC}$ located at the city of Tehran-Iran, the reinforced concrete buildings are laterally supported by dual system shear walls and moment resisting frames or moment resisting frames alone and mostly have flooring system of joists and blocks. These buildings have heights ranging from 16 to $75 \mathrm{~m}$ and are mostly regular or nearly regular in plan and height. All of the buildings are designed according to Iranian Seismic Code 2800 [48]. The city of Tehran, established on the southern foot of the Alborz range, and is bordered to the east by a mountainous series called "Sépayéh massif with average shear wave velocity $\mathrm{V}_{\mathrm{S}} \geq 400 \mathrm{~m} / \mathrm{s}[49]$.

\subsubsection{7buildings in Iran - Geomorphological zone II}

16 existing buildings are being studied, a brief description of the characteristics of the buildings is shown by M. Mirteheri (2018) [50]. 


\section{Results}

\subsection{Case study of Buildings in USA}

5.1.1 Van Nuys 7 story hotel

This section presents:

Table 5 and Table 6 present values of fundamental natural periods measured and calculated by different methods in EW and NS motion respectively: wave travel time's method, RPA2013 [51], Adeli [52] and SFSI models, with: $\mathrm{T}_{\text {beg }}$ : Apparent period of response at beginning of shaking, $\mathrm{T}_{\text {end }}$ : Apparent period of response at end of shaking, $\mathrm{T}_{\min }$ : Minimum value of apparent period during shaking, $\quad \mathrm{V}_{\mathrm{s}}$ : Shear Wave velocity $(\mathrm{m} / \mathrm{s}), \mathrm{I}_{\mathrm{F}}$ : Moment of inertia of the foundation, $\mathrm{I}_{\mathrm{St}}$ : Moment of inertia calculated of the structure only without SFSI, $\mathrm{W}_{\mathrm{S}}$ : Soil mass and $\mathrm{W}_{\mathrm{St}}$ : Total mass calculated from structure.

\subsubsection{The 40Buildings in California}

The fundamental periods obtained by ASCE7-10, UBC 97 [55], RPA 2013, Eurocode 8, Formulas Goel1997, Hang2000, Chopra2000, Crowley2006, Guler 2008, SFSI model and measured period data for longitudinal and traverse motions of 40 California buildings are listed in Table 8 . The comparative period calculation in measured and other authors are summarized in Table 9 and Table 10.

\subsection{Case study of Buildings in Europe}

\subsubsection{Buildings in Italy, Slovenia, Hungary and Macedonia}

Table 11 collected the periods and error obtained by Eurocode8, SFSI model and measured for 108buildings from 4 different European countries.

\subsubsection{Buildings in Greece}

Periods and error obtained by Eurocode 8, SFSI model and measured for 20buildings in Greece are summarised in Table 12.

\subsection{Case study of Buildings in Asia}

\subsubsection{Case study of 29 buildings in Iran}

Table 13 summarizes the error and identified periods obtained by IS2800, SFSI model and measured in Longest and Transversal plan dimension for 16 RC DWF and 13 RC MRF buildings in iran.

\subsubsection{Case study of 17 buildings in Iran}

In table 14, we summarize the error and identified periods obtained by IS2800, ASCE7-2015 [53], SFSI model and measured in Longest and Transversal plan dimension.

\section{Discussions}

An analysis of strong motion records for 215 buildings permit the following observations:

\subsection{Case study of Buildings in USA}

\subsubsection{Van Nuys 7 story hotel VN7SH}

In this study, it presents the effects of the magnitude, foundation and the soil:

-Effects of the magnitude: the effects of magnitude of lateral force due to an earthquake recorded motion on the response of building considering SFSI effects reaches: $22.9 \%$ when varying the magnitude from 4.1 to 7 .

-Effects of the foundation Fig.4: The application of the empirical formula given by the NEHRP94 code [54] leads to a fundamental period of $0.7 \mathrm{~s}$. The ratio $\mathrm{T}^{*} / \mathrm{T}_{\mathrm{NEHRP} 94}$ resulting from the latter gives $29.73 \%$ and $15.68 \%$ effects in the EW and NS directions respectively. This effect expresses the SFSI impact. It is observed that the ratios $\mathrm{T}^{*} / \mathrm{T}_{\mathrm{NEHRP} 94}$ in the two directions remain constant when varying the foundation inertia $\left(\mathrm{I}_{\mathrm{F}}=0 \mathrm{I}_{\mathrm{St}}\right.$ at $\left.0.1 \mathrm{I}_{\mathrm{ST}}\right)$. On the other hand, the effect reaches $18 \%$ when varying the mass foundation $\left(\mathrm{W}_{\mathrm{F}}=0 \mathrm{~W}_{\mathrm{St}}, \mathrm{W}_{\mathrm{F}}=0.25 \mathrm{~W}_{\mathrm{St}}\right.$ and $\left.\mathrm{W}_{\mathrm{F}}=0.50 \mathrm{~W}_{\mathrm{St}}\right)$.

-Effects of the soil Fig.5: The variation of soil masses $\left(\mathrm{W}_{\mathrm{S}}=0 \mathrm{~W}_{\mathrm{St}}, \mathrm{W}_{\mathrm{S}}=1 \mathrm{~W}_{\mathrm{St}}, \mathrm{W}_{\mathrm{S}}=2 \mathrm{~W}_{\mathrm{St}}\right.$ at $\left.\mathrm{W}_{\mathrm{S}}=5 \mathrm{~W}_{\mathrm{St}}\right)$ shows that under the same conditions an effect of $29.73 \%, 50.27 \%, 59.42 \%$, and $71.30 \%$ in the EW direction, and $15 \%, 40.44 \%, 51.36 \%$, and $65.60 \%$ in the NS direction. The Fig. 5 shows that the increase in soil masses increases the effect of the interaction, for example in the San Fernando earthquake, an increase of 1.3441 to 3.2928 is observed. The variation is about $59.18 \%$.

-Comparisons of SFSI model and the experimental response of theVN7SH Building during strong motion records have been presented in Table 7. The analytical models include the SFSI effects for vibrations in the NS and the EW directions, excellent agreement was found between the SFSI model and experimental values.

- For the same structure and the same site under different earthquakes, the dynamic response varies basically from $0.802 \mathrm{~s}$ to $1.646 \mathrm{~s}$. The variation is about 55\% as noted by Todorovska (Todorovska et al. 2001). Based on the work of Todorovska, the system frequency of a building can changes from one earthquake to another due to nonlinearity in the response of the foundation - soil (Todorovska et al. 2001).

- After the Big Bear earthquake with a magnitude of 6.5, the effect of the foundation inertia decreases roughly to reach the value of 1 which means that the SFSI effect is worthless. At the same time, the variation of the foundation mass remains above the value of 1 for the cases $\mathrm{W}_{\mathrm{F}}=0.25 \mathrm{~W}_{\mathrm{ST}}$ and $\mathrm{W}_{\mathrm{F}}=0.50 \mathrm{~W}_{\mathrm{ST}}$. At the same point, the variation of the soil mass remains above 1.5.

- A good correlation for EW motions between:

-Wave travel times of vertically propagating waves solution and analytical model proposed by SFSI model without soil foundation masses with average of $4.67 \%$-Table $5 \mathrm{~A}$.

-Wave travel times of vertically propagating waves solution and Adeli with average of $2.37 \%$.

- It shows an important averge for EW direction between measured period and Adeli it is about $20.53 \%$. 
- It should be noted that due to SFSI effect, large increases in the value of period "effective ground period > 1.25" are not common in relatively tall yet rigid structures founded on soft soil.

6.1.2 40Buildings in California

-A good correlation between measured period and SFSI model about $6.80 \%$ and $0.33 \%$ in longitudinal and transverse motion respectively Table 9 and Table 10, as showed in Fig.6 and Fig.7.

- Lower limit fundamental periods obtained from the recommended formula proposed by Goel and Chopra are less than those measured, $13.40 \%$ in longitudinal motion and $24.12 \%$ in transverse motion.

- Upper limit fundamental periods obtained from the recommended formula proposed by Goel and Chopra are more than those measured, $21.11 \%$ in longitudinal motion and $13.64 \%$ in transverse motion.

- Fundamental periods obtained from ASCE 7-10 are consistently less than those measured, $13.43 \%$ and $24.18 \%$ in longitudinal and transverse motion respectively.

-Table.13 show that the fundamental periods obtained from Eurocode 8, RPA2003 and IS2800 are consistently less than those measured, $19.75 \%$ and $31.78 \%$ in longitudinal and transverse motion respectively.

-Expressions for the evaluation of fundamental period of vibration by Hong and Hwang are consistently less than those measured, $177.03 \%$ and $154.59 \%$ in longitudinal and transverse motion respectively.

-Formula proposed by Crowley and Pinho (2004) are less than those measured, $11.18 \%$ in longitudinal motion and $21.31 \%$ in transverse motion.

\subsection{Case study of Buildings in Europe}

\subsubsection{Buildings in Italy, Slovenia, Hungary and Macedonia}

The data shown in Table 11 for all buildings allow for the following observations:

- The code formulas given by Eurocode 8 of RC buildings have high correlations with calculted by SFSI model about $99 \%$, but leads to periods significantly greater than measured periods of $39.27 \%$ and $48.42 \%$ in SFSI model and Eurocode 8 respectivelyFig. 8 and Fig.9.

\subsubsection{Buildings in Greece}

-The comparison on a test building between measured and SFSI model shows a very small error in the fundamental periods. A difference about $8.16 \%$ showed in Table 12 and Fig. 10.

\subsection{Case study of Buildings in Asia}

\subsubsection{Buildings in Iran}

The data shown in Table 13 for all buildings allow the following observations:

For 16 RC DWF buildings:

- Average difference between measured period and SFSI model about $4.28 \%$ and $20.19 \%$ in longitudinal and transverse motion respectively - Fig. 11 and Fig. 12.

- The proposed formulas given by IS2800 of RC buildings have high correlations with measured about $79.64 \%$ and $74.53 \%$ in longitudinal and transverse motion respectively.

For 13 RC MRF buildings:

- A good correlation between measured period and SFSI model about $80.04 \%$ and $99.9 \%$ in transverse and longitudinal motion respectively - Fig.13 and Fig.14.

- The proposed formulas given by IS2800 of RC buildings have high correlations with measured about $80.04 \%$ and $72.89 \%$ in longitudinal and transverse motion respectively.

\subsubsection{RC MRF Buildings in Iran}

For all buildings in Iran permit the following observations:

- The natural measured period of vibration has on average a difference of about $2.52 \%$ in longitudinal and $23.26 \%$ in transverse motion with those obtained from the SFSI model Table 14.

- The average difference between the measured period of vibration obtained from the ASCE-7-2015 and those obtained from the measured ranges from $105.58 \%$ to $135.66 \%$ in longitudinal and transverse motion respectively. Same as before, this can indicate that the empirical relationships of the ASCE-7-2015 suggested to calculate the natural measured period are not accurate enough.

- The difference between the measured period of vibration obtained from the IS2800 and those obtained from the measured ranges from $52.07 \%$ to $79.51 \%$ in longitudinal and transverse motion respectively.

\section{Conclusions}

- The value of period of vibration changes from one earthquake to another as a principal function due to the soil mass.

- Soil effect has a great influence on the naturel period more than that of the foundation.

- Height of buildings strongly affects the fundamental period.

- $\quad$ Earthquake response reduction effects by SFSI are affected by the number of stories.

- $\quad$ SFSI strongly affects the fundamental period, where the more flexible the soil, the larger the fundamental period.

- Analysis of the fundamental period can be used by mean of wave travel times method such as solution in a building with shear wave velocity $\mathrm{V}_{\mathrm{S}} \geq 360 \mathrm{~m} / \mathrm{s}$.

- $\quad$ SFSI effect is very important in the cases of: flexible structure on a very losse site, flexible structure on a stiff soil and rigid structure on a very losse site. 


\subsection{Proposed empirical expression:}

In this section, an empiricals equations for estimating the fundamental period of RC MRF and RC DWF buildings are proposed considering the SFSI effects can be taken as the equations below:

\subsubsection{Case study of RC MRF buildings:}

Geomorphological Site I: $\quad T_{\text {SFSI }}=0.143 \mathrm{H}^{0.638}$
Geomorphological Site II: $\mathrm{T}_{\mathrm{SFSI}}=0.063 \mathrm{H}^{0.700}$
Geomorphological Site III: $\mathrm{T}_{\mathrm{SFSI}}=0.062 \mathrm{H}^{0.804}$

7.1.2 Case study of RC DWF buildings:

$$
\begin{aligned}
& \text { Geomorphological Site I: } \mathrm{T}_{\mathrm{SFSI}}=0.250 \mathrm{H}^{0.340} \\
& \text { Geomorphological Site II: } \mathrm{T}_{\mathrm{SFSI}}=0.105 \mathrm{H}^{0.635} \\
& \text { Geomorphological Site III: } \mathrm{T}_{\mathrm{SFSI}}=0.079 \mathrm{H}^{0.700}
\end{aligned}
$$

Where, $\mathrm{H}$ is height of building from the base in (m).

\section{Recommendations}

- Seismic codes in many parts of the world suggest ignoring SFSI studies for seismic design of structures However, for a structure resting on soil, it is imperative that the interaction effects to be considered during its analysis.

- It is recommended to include empirical period formula in code seismic including soil properties beside height $\mathrm{H}$.

- Revised periodically the proposed expressions by expanding database of instrumented buildings.

- The proposed expressions for fundamental period of building type RC MRF and RC DWF may not be valid for RC SW buildings.

- In future, expressions for fundamental period of building type RC SW considering the SFSI effects should be proposed and stated separately in other works.

\section{Availability of data and materials}

The datasets used during the current study are available from the corresponding author on reasonable request.

SFSI: Soil foundation and structure interaction

\section{Abbreviations}

VN7SH: Van Nuys 7 story hotel

RC: Reinforced Concrete buildings

RC MRF: Reinforced Concrete buildings with moment resisting frames

RC DWF: Reinforced Concrete buildings with dual wall frame

RC SW: Reinforced Concrete buildings with shear wall system

PGA: Peak ground acceleration

WTT: Wave travel times method

AFPS: French Association of Earthquake Engineering

ASCE-7: American Society of Civil Engineers

NEHRP94: Recommended Provisions for the development of Seismic Regulations for New Buildings

IS2800 : Iranian Seismic Code 2800

RPA2013: Algerian seismic code

UBC97: Uniform Building Code

EC8 : Eurocode 8

Long : Longitudinal motion

Trans : Transversal motion

UPER: Uper limit according to Goel and Chopra

LOW: Lower limit according to Goel and Chopra

Beg: Response during 12 Earthquakes at beginning of Shaking

End: Response during 12 Earthquakes at end of Shaking

Min: Minimum Value during Shaking

EW : east-west direction

NS: north-south direction 


\section{References}

[1] C. S. Oliveira - M. Navarro. (2010), Fundamental periods of vibration of RC buildings in Portugal from in-situ experimental and numerical techniques, Bull Earthquake Eng 8, PP609-642, DOI 10.1007/s10518-009-9162-1

[2]W. Bourouaiah, S. Khalfallah \& S. Boudaa. (2019), Influence of the soil properties on the seismic response of structures, Springer Link, International Journal of Advanced Structural Engineering volume 11, PP 309-319

[3] V. Davidovici, Eurocode8. (2013), Pratique du calcul sismique, Guide d'application, Afnor éditions -Eyrolles.

[4] AFPS et CMFS. (2012), Guide technique, Procédés d'amélioration et de renforcement de sols sous actions sismiques, Presse des Ponts.

[5] K. Pitilakis, C. Gazepis, A. Anastasiadis. (2004), Design response spectra and soil classification for seismic code provisions, 13th World Conference on Earthquake Engineering Vancouver, B.C., Canada August 1-6, Paper No. 2904.

[6] A. Piro, F. de Silva, F. Parisi, A. Scotto di Santolo \& F. Silvestri. (2020), Effects of soil-foundation-structure interaction on fundamental frequency and radiation damping ratio of historical masonry building sub-structures, Springer Link, Bulletin of Earthquake Engineering volume 18, PP 1187-1212

[7] HA. Smith, Wu WH, RI. Borja. (1994), Structural control considering soil-structure interaction effects. Earthq Eng Struct Dyn 23: PP 609-626.

[8] S.E. Abdel Raheem, M.M. Ahmed \& T.M. A. Alazrak. (2015), Evaluation of soil-foundation-structure interaction effects on seismic response demands of multi-story MRF buildings on raft foundations, Springer Link, International Journal of Advanced Structural Engineering (IJASE) volume 7, PP 11- 30.

[9] R. Fares, M.P. Santisi d'Avila, A. Deschamps. (2019), Soil-Structure Interaction analysis using a 1DT-3C wave propagation model, Soil Dynamics and Earthquake Engineering 120, PP 200-213, DOI: 10.1016/j.soildyn.2019.02.011

[10] DT. Mihailo, IT. Maria, H. Tzong-Ying. (2001), Full-scale experimental studies of soil structure interaction, In: Proceedings of the 2nd US-Japan workshop on soil structure interaction, Tsukuba City, Japan, March 6-8.

[11] M.I. Todorovska and M.D. Trifunac. (2008), Impulse response analysis of the Van Nuys 7 story hotel during 11 earthquakes and earthquake damage detection, The journal of the international association for structural control and monitoring, Structural Control Health Monitoring, Vol.15, Issue.1, pp.90-116, DOI: $10.1002 /$ stc. 208.

[12] H. Torkia \& N. Lahbari. (2020), Inertial interaction effects analysis on the estimating of dynamic amplification factor for reinforced concrete structures, Journal of Building Pathology and Rehabilitation, springer, Volume 5, Number 1, PP1-24, DOI 0.1007/s41024-020-00078-y

[13] B.R. Jayalekshmi, H.K. Chinmayi. (2013), Effect of soil flexibility on lateral natural period in RC framed buildings with shear wall, International Journal of Innovative Research in Science, Engineering and Technology Vol. 2, Issue 6.

[14] I. Kraus \& D. Džakić. (2013), Soil-structure interaction effects on seismic behaviour of reinforced concrete frames, 50 SE -EEE University of Osijek, Faculty of Civil Engineering Osijek, Croatia.

[15] Eurocode8. (1994), Structures in seismic regions, Part 5: Foundations, Retaining Structures, and Geotechnical Aspects.

[16] PW. John, S. Chongmin. (2002), Some cornerstones of dynamic soil-structure interaction, Eng Struct 24: PP13-28.

[17] L. Khalil. (2009), Influence de l'interaction sol-structure sur le comportement sismique des bâtiments : analyse dans les domaines linéaire et non linéaire, thèse de doctorat, Université lille1.

[18] Goel R.K, Chopra A.K (1997).” Period formulas for moment resisting frame buildings.” J. Struct. Eng, 10.1061/ (ASCE) 0733-9445(1997)123:11(1454), PP 1454 -1461, https://doi.org/10.1061/(ASCE)0733-9445(1997)123:11(1454)

[19] Goel R.K, Chopra A.K (1998)." Period formulas for concrete shear wall buildings.” J. Struct. Eng, 10.1061/ (ASCE) 0733-9445(1998)124:4(426), PP 426-433, https://doi.org/10.1061/(ASCE)0733-9445(1998)124:4(426)

[20] K. Guler, E. Yuksel, and A. Kocak. (2008), Estimation of the Fundamental Vibration Period of Existing RC Buildings in Turkey Utilizing Ambient Vibration Records, Journal of Earthquake Engineering, 12(S2): PP 140-150, DOI: 10.1080/13632460802013909

[21] Li. L.H and Hwang W.L. (2000), Empirical formula for fundamental periods of vibration for Reinforced concrete buildings in Taiwan Earthquake Engineering and Structural Dynamics, 29, PP 327-337

[22] H. Crowley and R. Pinho. (2004), period-height relationship for existing European reinforced concrete buildings, Journal of Earthquake Engineering, Vol. 8, Special Issue 1, PP 93-119 Imperial College Press.

[23] Lee, L.-H.; Chang, K.-K.; Chun, Y.-S. (2000), Experimental Formula for the Fundamental Period of RC Buildings with Shear-Wall Dominant System. // The Structural Design of Tall Build. 9, PP 295-307. DOI:10.1002/1099-1794(200009)9:4<295::AID-TAL153>3.0.CO;2-9

[24] M. Hadzima-Nyarko, D. Morić, H. Draganić, T. Štefić. (2015), comparison of fundamental periods of reinforced shear wall dominant building models with empirical expressions, Strojarski fakultet u Slavonskom Brodu, Elektrotehnički fakultet u Osijeku, Građevinski fakultet u Osijeku DOI: 10.17559/TV-20140228124615

[25] H. Crowley and R. Pinho. (2006), simplified equations for estimating the period of vibration of existing buildings, First European Conference on Earthquake Engineering and Seismology (a joint event of the 13th ECEE \& 30th General Assembly of the ESC) Geneva, Switzerland, 3-8 September 2006 Paper Number: 1122

[26] O.S. Kwon, E.S. Kim. (2010), Evaluation of building period formulas for seismic design. // Earthquake Engineering and Structural Dynamics. 39, 14(2010), PP 1569-1583. DOI: 10.1002/eqe.998

[27] M.H. Nyarko, D. Morić, H. Draganić, T. Štefić. (2015), comparison of fundamental periods of reinforced shear wall dominant building models with empirical expressions, Strojarski fakultet u Slavonskom Brodu, Elektrotehnički fakultet u Osijeku, Građevinski fakultet u Osijeku DOI: 10.17559/TV-20140228124615

[28] H. Elgohary. (2013), Empirical formula for the fundamental period of vibration of multi-storey RC framed buildings Proceeding of Vienna Congress on Recent Advances in Earthquake Engineering and Structural Dynamics Vienna, Austria August.

[29] S. Prakash and SK. Dubey. (2015), Effect of base width and stiffness of the structure on period of vibration of RC framed buildings in seismic analysis Open Journal of Earthquake Research 4, PP 65-73.

[30] MR. Gallipoli, M. Mucciarelli, M. Vona. (2009), Empirical estimate of fundamental frequencies and damping for Italian buildings, Earthquake Engineering and Structural Dynamic Vol. 38, PP 973-988.

[31] H. Crowley and R. Pinho. (2010), Revisiting Eurocode 8 formulae for periods of vibration and their employment in linear seismic Analysis, Earthquake Engineering and Structural Dynamics; Vol. 39(2), PP 223-235.

[32] Al-Nimry, N., Resheidat, M. and Al-Jamal, M. (2014), Ambient vibration testing of low and medium rise in-filled RC frame buildings in Jordan, Soil Dynamics and Earthquake Engineering Vol.59, PP 21-29.

[33] G.A. Panagiotis, C.R. Constantinos, L. Cavaleri, V. Sarhosis and A. Athanasopoulou. (2015), On the fundamental period of infilled RC frame buildings, Structural Engineering and Mechanics, Vol. 54, No. 6, PP 1175-1200, DOI: http://dx.doi.org/10.12989/sem.2015.54.6.1175

[34] A. K. Chopra and R. K. Goel. (200), Building period formulas for estimating seismic displacements, Earthquake Spectra, vol. 16, no. 2, PP 533-536.

[35] K. Guler, E. Yuksel, and A. Kocak. (2008), Estimation of the fundamental vibration period of existing RC buildings in Turkey utilizing ambient vibration records, Journal of Earthquake Engineering, vol. 12, supplement 2, PP 140-150.

[36] P. Sangamnerkar and S.K. Dubey. (2017), Equations to evaluate fundamental period of vibration of buildings in seismic analysis, Structural Monitoring and Maintenance, Vol 4, No 4, PP 351-364, DOI: https:// doi.org/10.12989/smm.2017.4.4.351.

[37] M. Gatti. (2018), Elastic period of vibration calculated experimentally in buildings hosting permanent GPS stations, earthquake engineering and engineering vibration, Vol.17, No.3, PP 607-625 DOI: https://doi.org/10.1007/s11803-018-0466-5

[38] T. Haitem, N. Lahbari. (2015), Seismic response model including SSI of RC buildings on isolated and raft foundations, International Journal of Civil Engineering and Technology, IAEME, Volume 6, Issue 3, PP 118-131.

[39] Todorovska M.I, Ivanovic S.S, Trifunac M.D (2001).” Wave propagation in a seven-story reinforced concrete building I. Theoretical models.” Soil dynamics and Earthquake Engineering, Elsevier, Vol.21, Issue.3, pp.211-223, DOI: 10.1016/S0267-7261(01)00003-3.

[40] M.I. Todorovska and M.D. Trifunac (2008)." Impulse response analysis of the Van Nuys 7 story hotel during 11 earthquakes and earthquake damage detection.”, the journal of the international association for structural control and monitoring, Structural Control Health Monitoring, Vol.15, Issue.1, PP 90-116, DOI: $10.1002 /$ stc. 208 .

[41] V. Gicev, M.D Trifunac (2007)." Energy and power of nonlinear waves in a seven-story reinforced concrete building." Journal of Indian Society of Earthquake Technology, ISET, Paper No. 487, Vol. 44, No. 1, PP 305-323

[42] M.D Trifunac, S.S Ivanovic and M.I Todorovska (1999).” Instrumented 7-storey reiforced concrete building in Van Nuys.” California: Description of the 
damage from the 1994 Northridge earthquake and strong motion data, Report CE 99-02, Los Angeles, California.

[43] K.A Porter, J.L Beck, J.Y Ching, J. Mitrani-Reiser, M. Miyamura, A. Kusaka, T. Kudo, K. Ikkatai, Y. Hyodo (2004), Real-Time Loss Estimation For Instrumented Buildings, earthquake Engineering Research Laboratory, Report EERL 2004-08, Pasadena, California, ID Code 26545.

[44] Naeim F, Alimoradi A, Miranda E (2005), Automated Post-Earthquake Damage Assessment and Safety Evaluation of Instrumented Buildings, JAMA Report number: 10639.

[45] S. Magdy. (2015), Estimation of period of vibration for concrete moment-resisting frame buildings, HBRC Journal Volume 11, Issue 1, April 2015, Pages 1621, https://doi.org/10.1016/j.hbrcj.2014.01.006

[46] M. R. Gallipoli · M. Mucciarelli · B. Šket-Motnikar · P. Zupan 'ci’ · A. Gosar · S. Prevolnik · M. Herak · J. Stip cevi' · D. Herak · Z. Milutinovi’c · T. Olum'ceva; (2010), Empirical estimates of dynamic parameters on a large set of European buildings, Bull Earthquake Eng, 8: PP 593-607, Springer Science+Business Media B.V. 2009, DOI 10.1007/s10518-009-9133-6

[47] G.D. Hatzigeorgiou, G. Kanapitsas. (2013), Evaluation of fundamental period of low-rise and mid-rise reinforced concrete buildings, earthquake engineering \& structural dynamics Earthquake Engng Struct. Dyn. 2013; 42: PP1599-1616 DOI: 10.1002/eqe.2289

[48] A. Jalali, A.S Milani. (2005), fundamental periods of buildings measured from ambient vibration measurements, the 2005 world sustainable building conference, Tokyo, 27-29 September.

[49] E. Haghshenas. (2005), Conditions Geotechnique et Alea Sismique Local a Teheran, Thèse, l'Université Joseph Fourier - Grenoble I, France, HAL Id: tel-00010960

[50] M. Mirtaheri, F. Salehi.(2018), Ambient vibration testing of existing buildings: Experimental, numerical and code provisions, Advances in Mechanical Engineering 2018, Vol. 10(4) 1-9, DOI: 10.1177/1687814018772718

[51] RPA2003. (2003), Règles parasismiques Algériennes 1999 - Version 2003. DTR-BC 248 - CGS, Alger.

[52] H. Adeli. (1985), Approximate formulae for period of vibrations of building systems, civil engineering for practising and design engineers, Vol4 Nb1 PP93-128, Junnary 1985.

[53] ASCE Minimum Design Loads and Associated Criteria for Buildings and Other Structures. ASCE/SEI 7-15: American Society of Civil Engineers, USA, 2015.

[54] NEHRP. 1994, Recommended Provisions for the development of Seismic Regulations for New Buildings, Building Seismic Safety Council, Washington, D. C., 1994.

[55] Uniform Building Code, Structural Engineering Design Provisions, Volume 2. International Conference of Building Officials, USA 1997.

Not applicable.

\section{Acknowledgements}

\section{Funding}

Not applicable.

Affiliations

Author information

Institute of architecture and urbanism, LAUTr laboratory, University of Batna 1, Algeria

Torkia Haitem

Department of Civil Engineering, Faculty of Technology, University of Batna 2, Algeria

Maalem Toufik, Lahbari Noureddine

\section{Contributions}

Torkia Haitem, Maalem Toufik and Lahbari Noureddine dsigned the research. T.H wrote the manuscript with support by M.T and L.N. all authors read and approved the final manuscript.

Corresponding author

Correspondence to Torkia Haitem

\section{Competing interests}

\section{Ethics declarations}

The authors declare that they have no competing interests. 
Figures

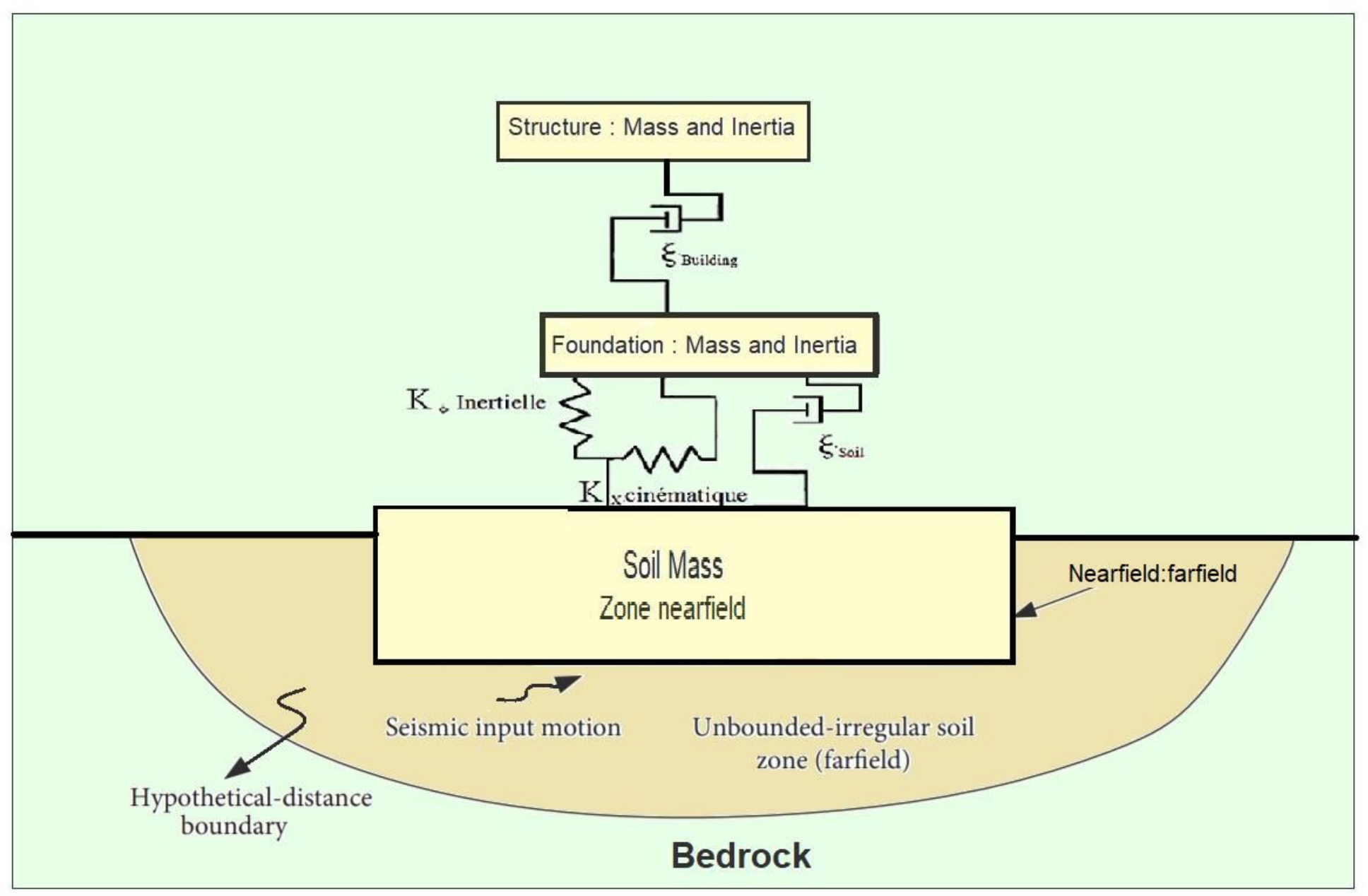

\section{Figure 1}

Shematic proposed model of SFSI interaction included inertiel and kinematic interactions. 


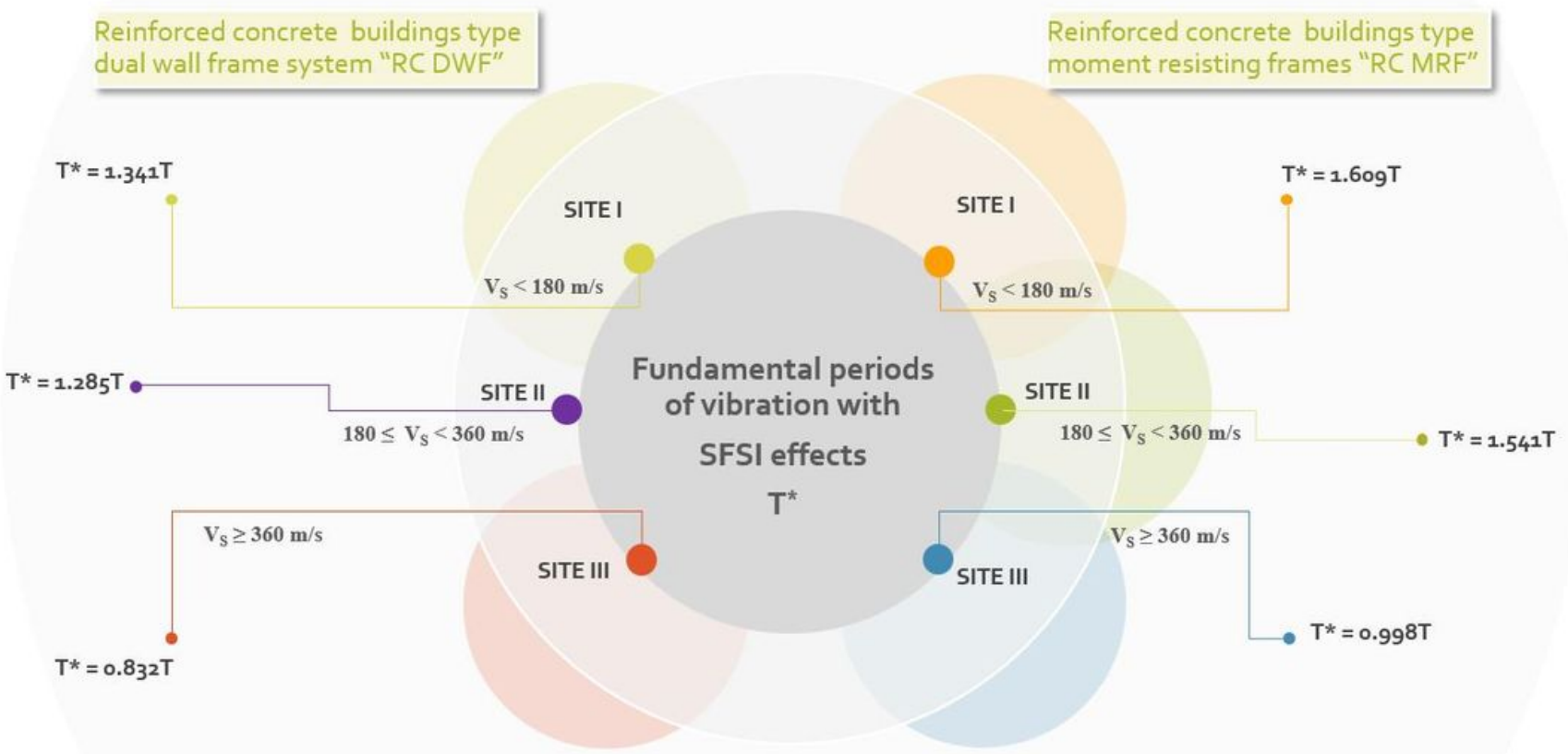

Figure 2

Flowchart of the simplified equation for estimating fundamental periods of vibration with SFSI effects of Reinforced Concrete buildings.

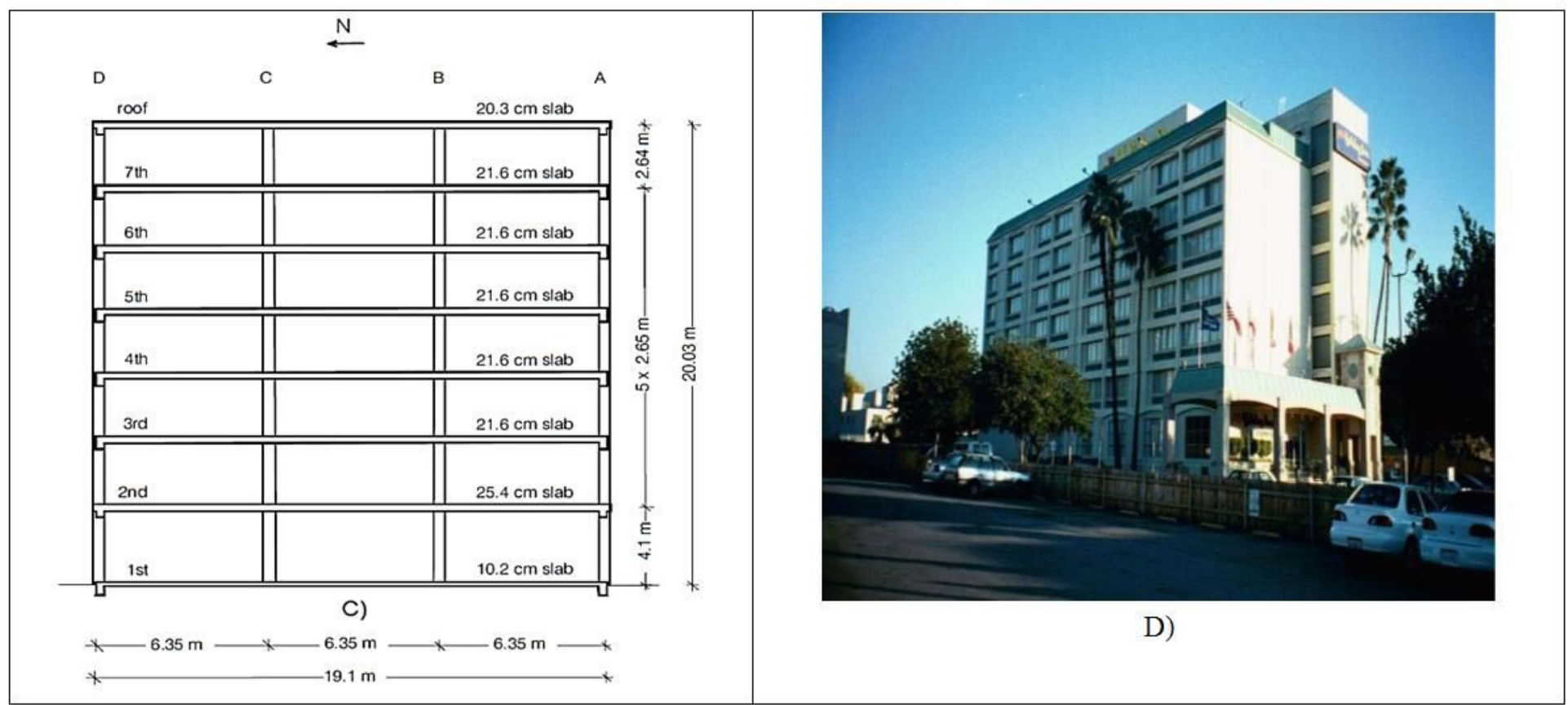

\section{Figure 3}


VN7SH building: (a) typical floor plan, (b) foundation plan, (c) typical transverse section and (d) VN7SH South West elevation [40] and [44].

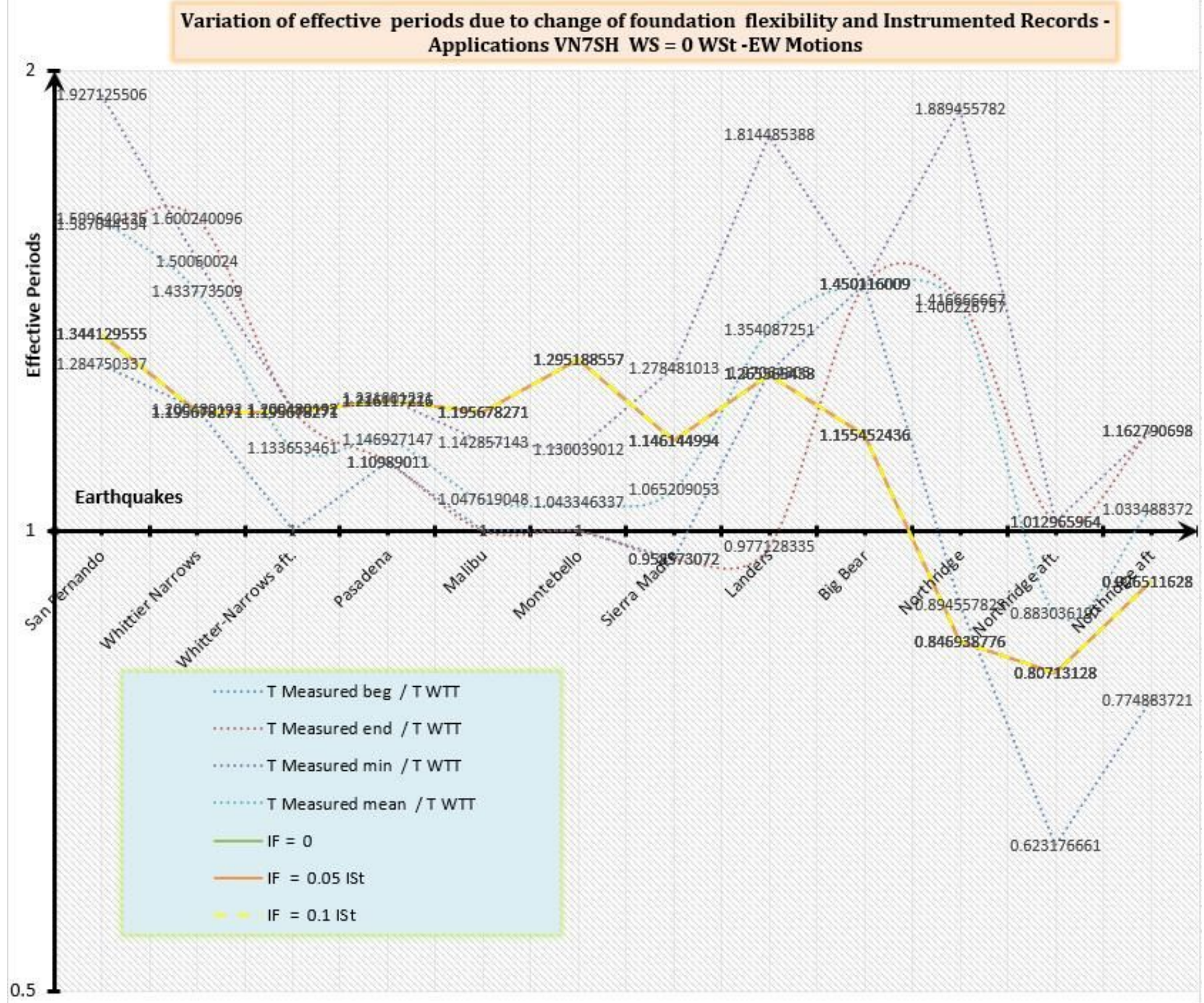

Figure 4

Effect of foundation inertia in VN7SH for 24 years. 


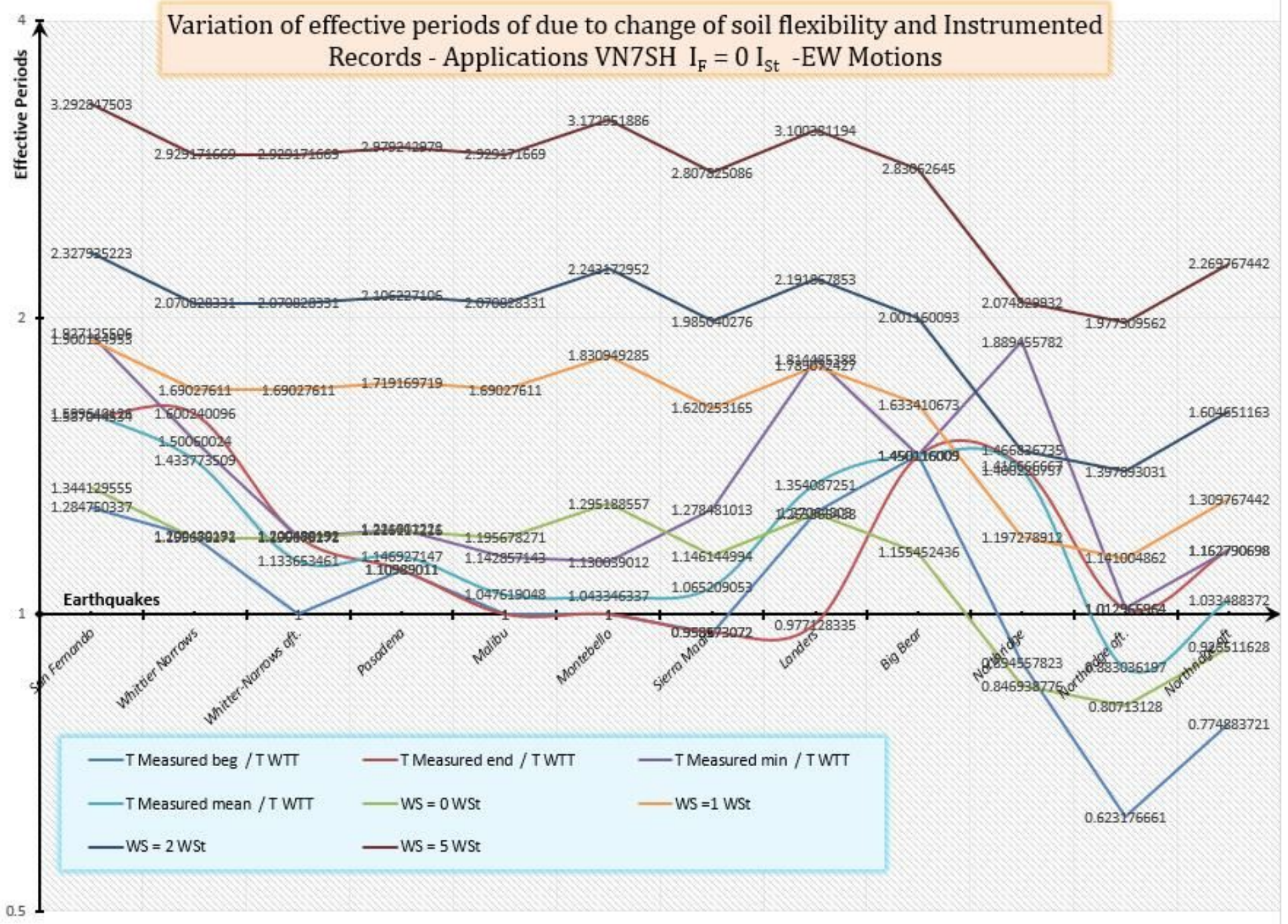

Figure 5

Effect of soil mass in VN7SH for 24 years. 


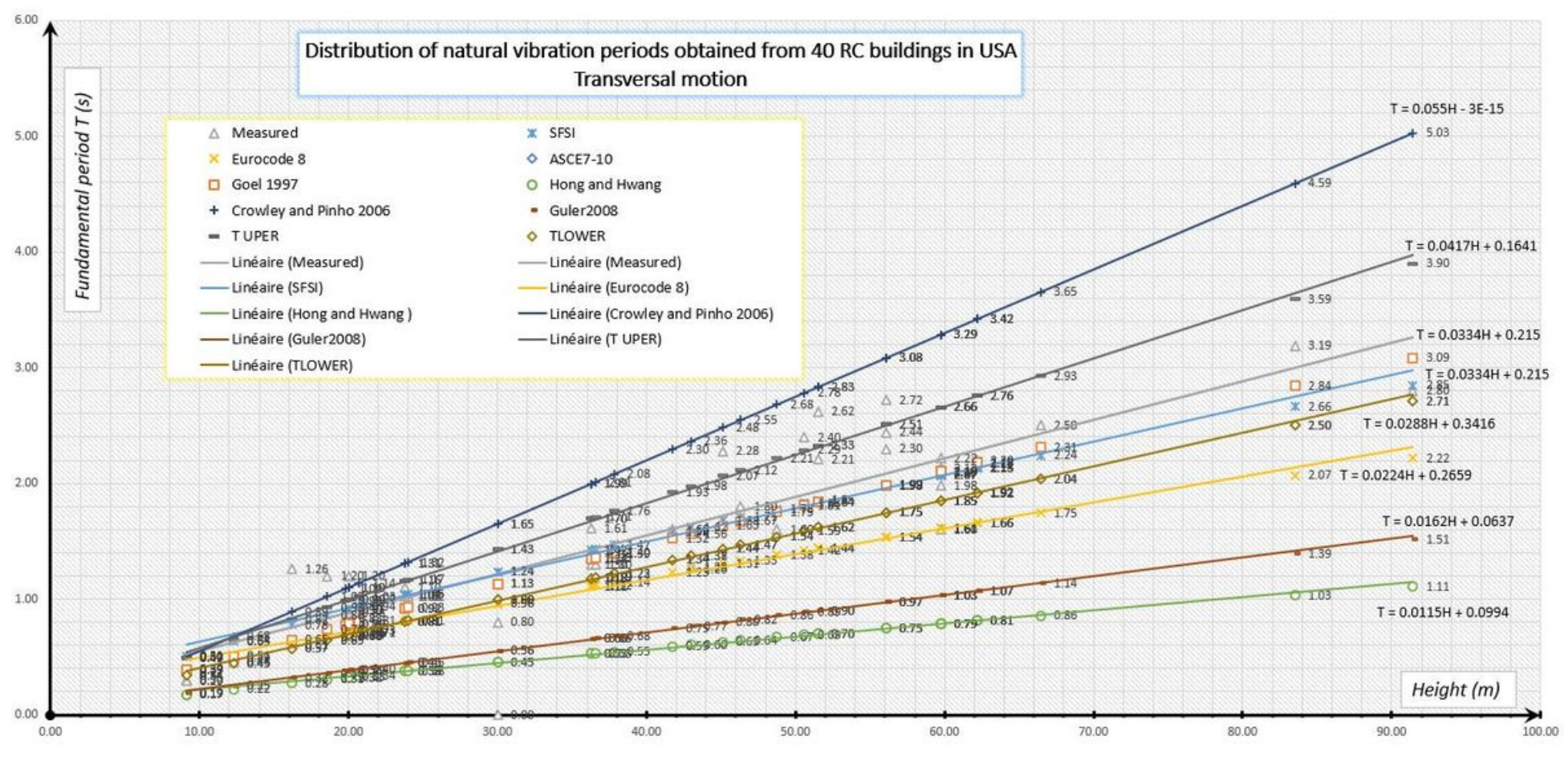

\section{Figure 6}

Variation in lateral period value due to change in height in transverse motions from 40RC buildings in USA - Site II.

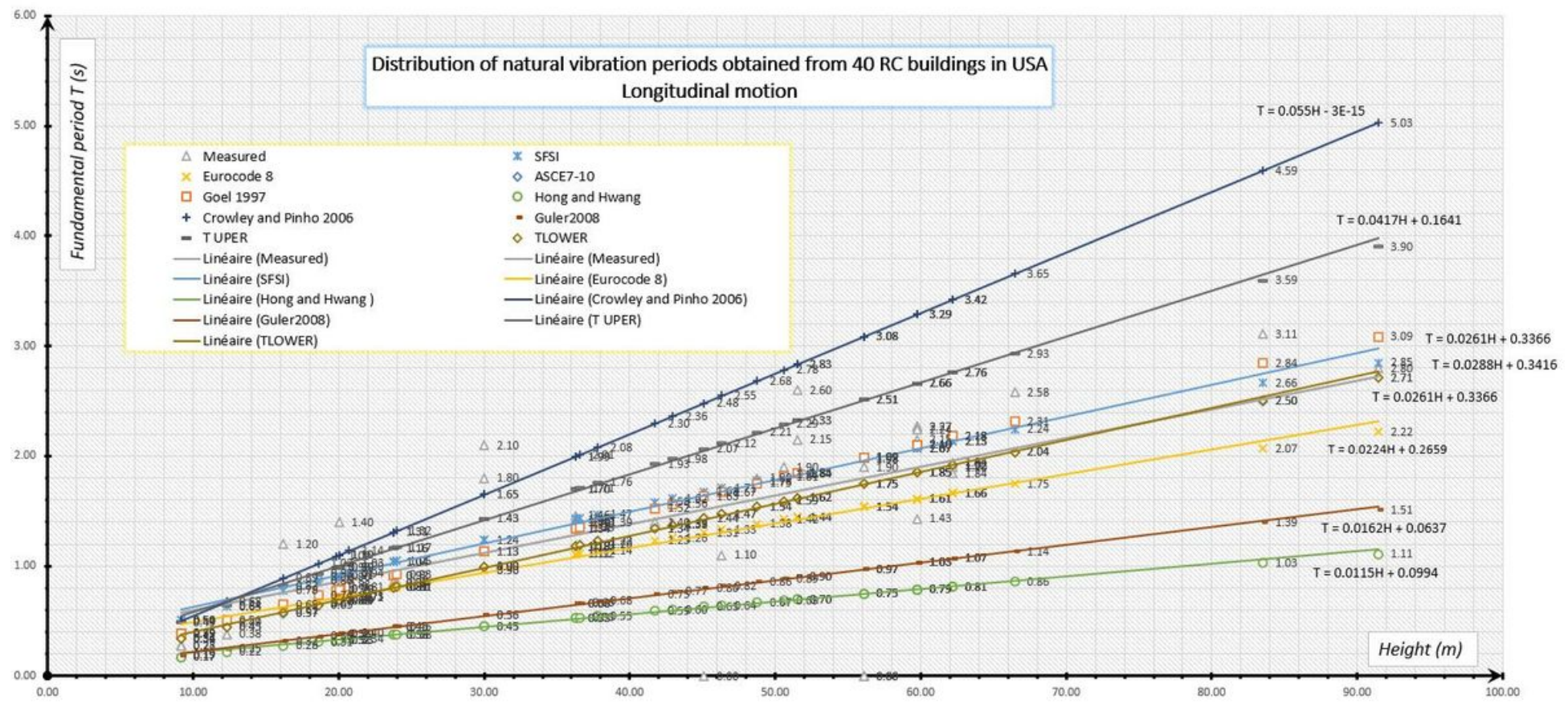

Figure 7

Variation in lateral period value due to change in height in longitudinal motions from 40RC buildings in USA - Site II. 


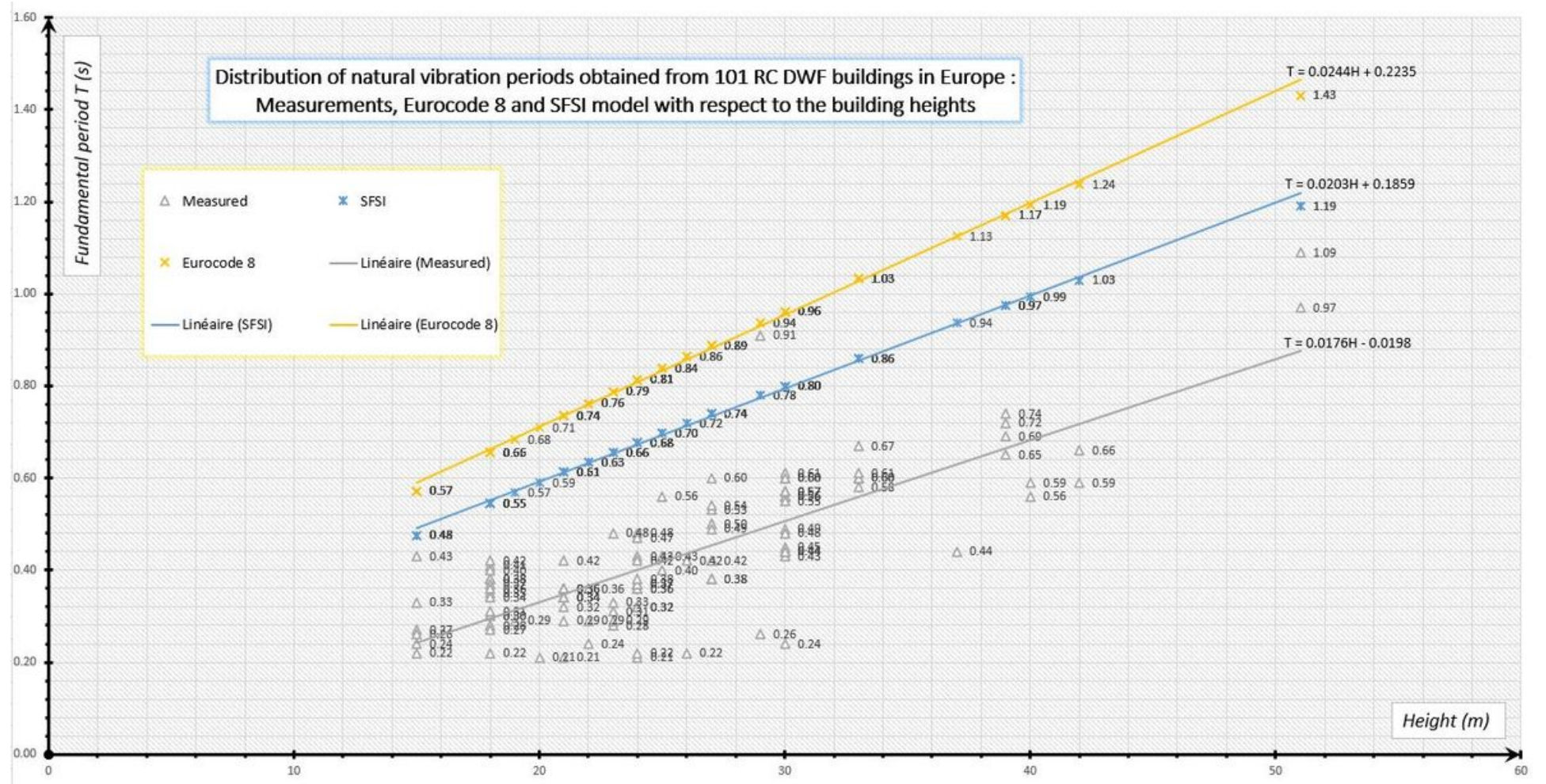

Figure 8

Variation in lateral period value due to change in height from 101 RC DWF buildings in Europe - Site III.

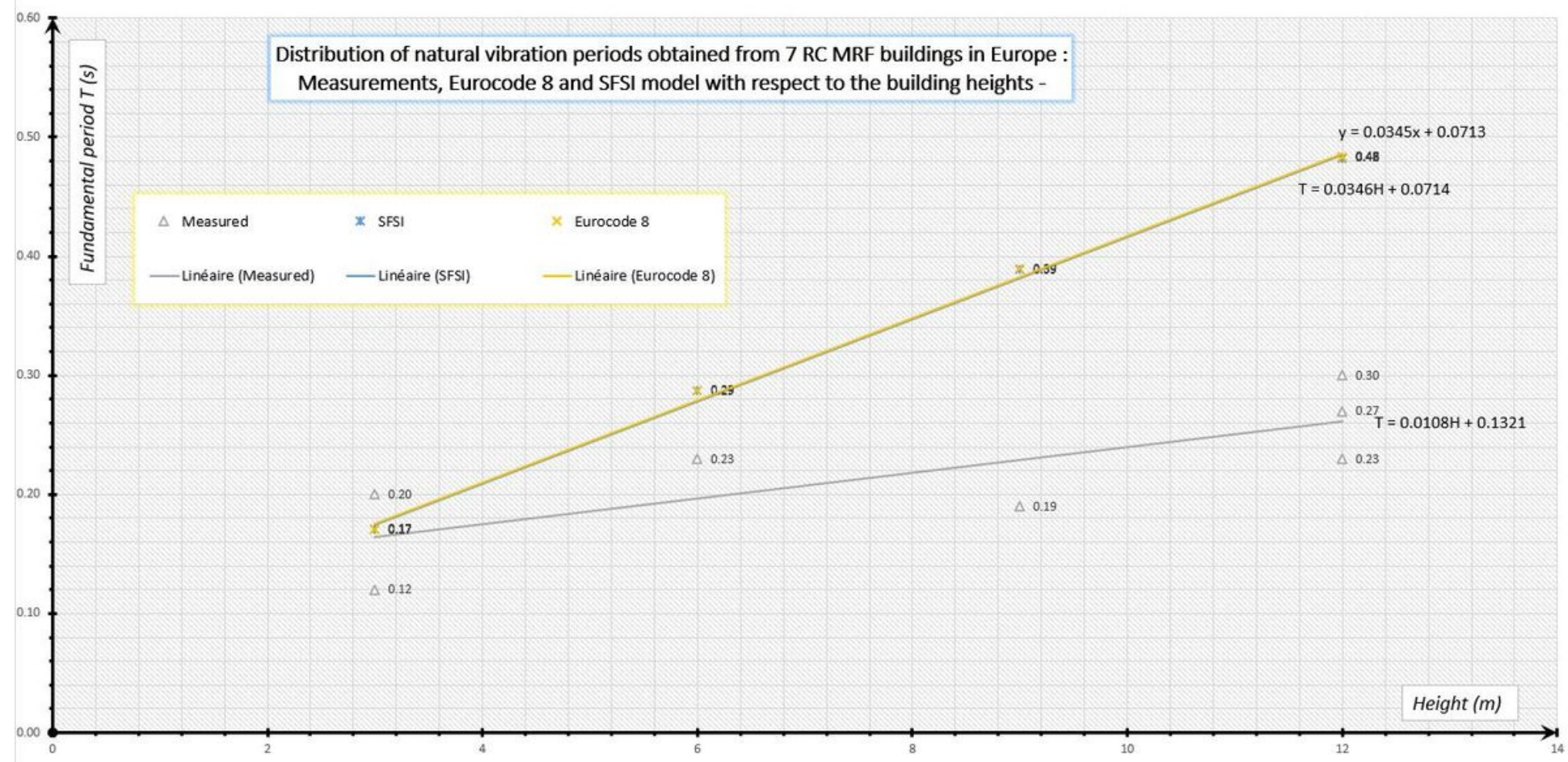

Figure 9

Variation in lateral period value due to change in height from 7 RC MRF buildings in Europe - Site III. 


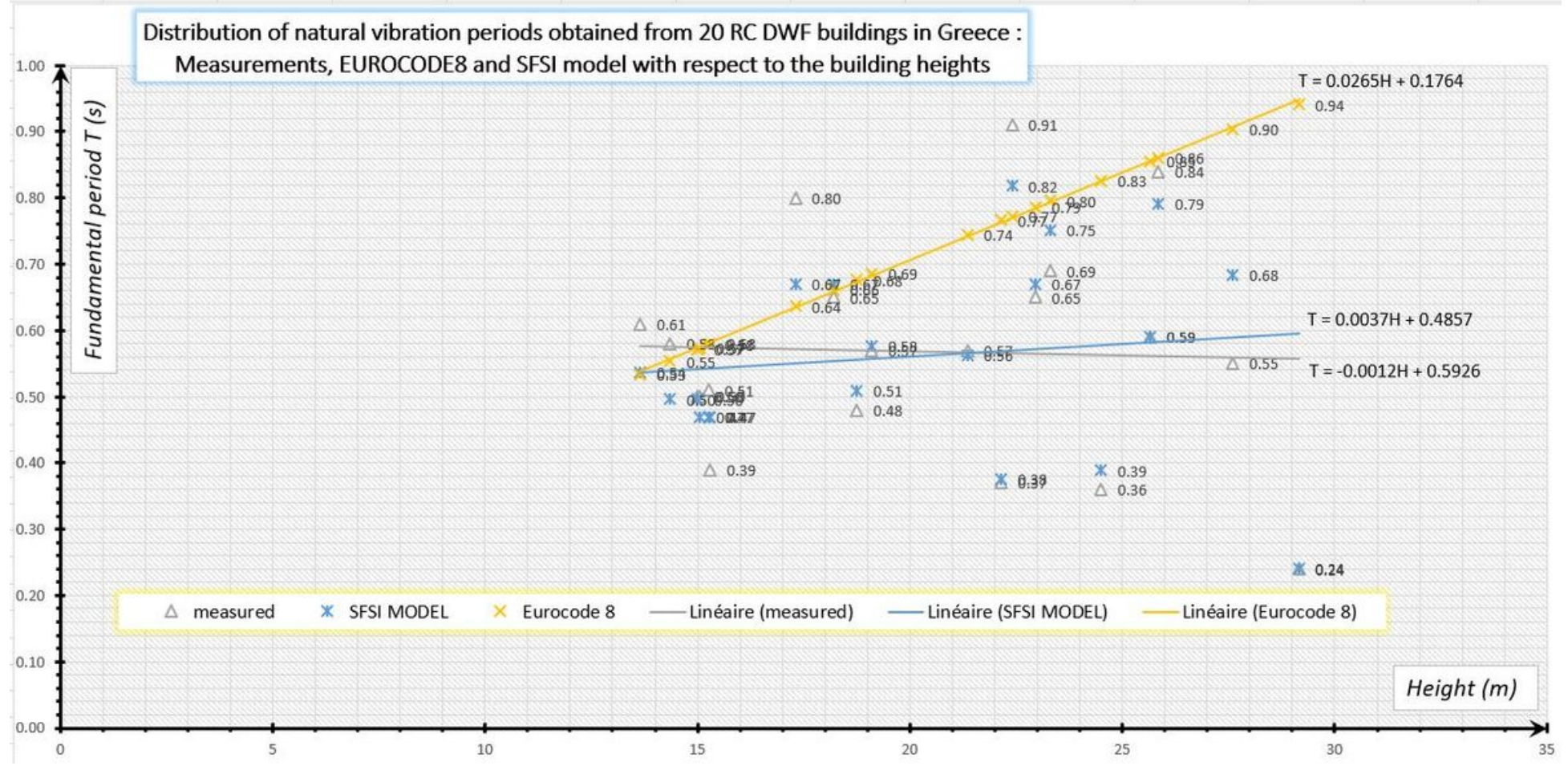

Figure 10

Variation in lateral period value due to change in height from 20 RC DWF buildings in Greece - Site I.

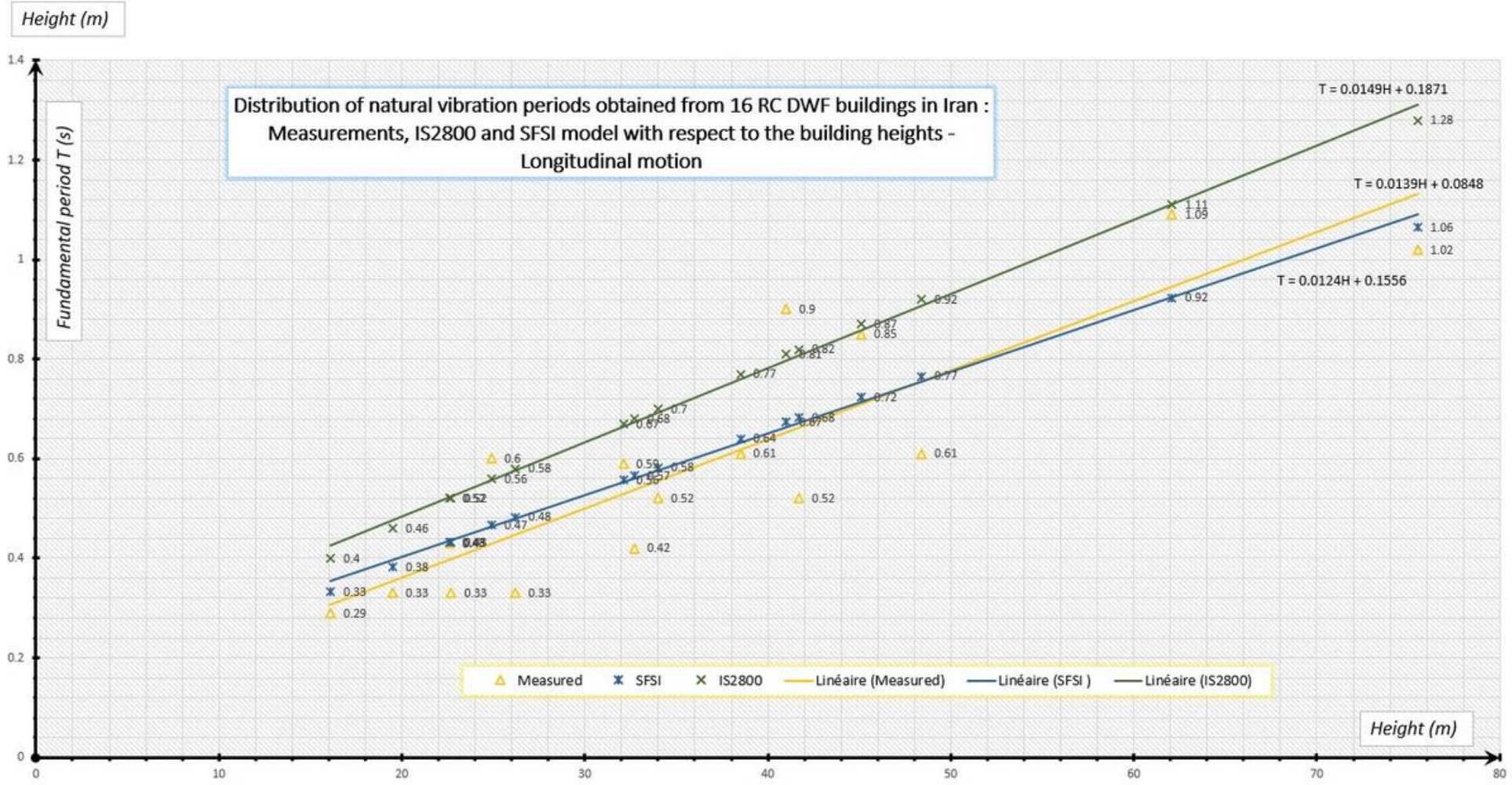

\section{Figure 11}

Variation in lateral period value due to change in height from 16 RC DWF buildings in Iran - Longitudinal motion Site II. 


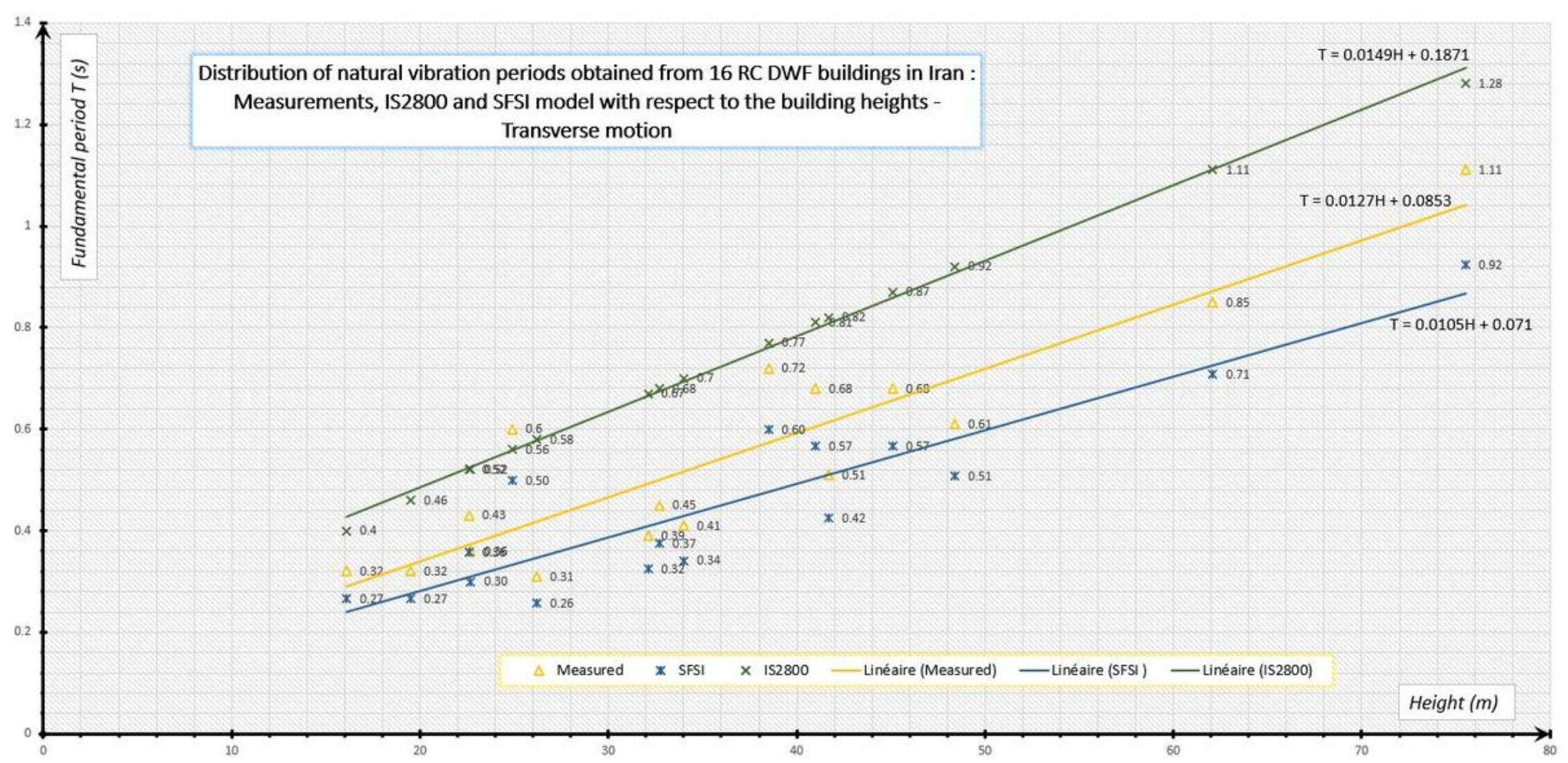

Figure 12

Variation in lateral period value due to change in height from 16 RC DWF buildings in Iran - Transverse motion Site II.

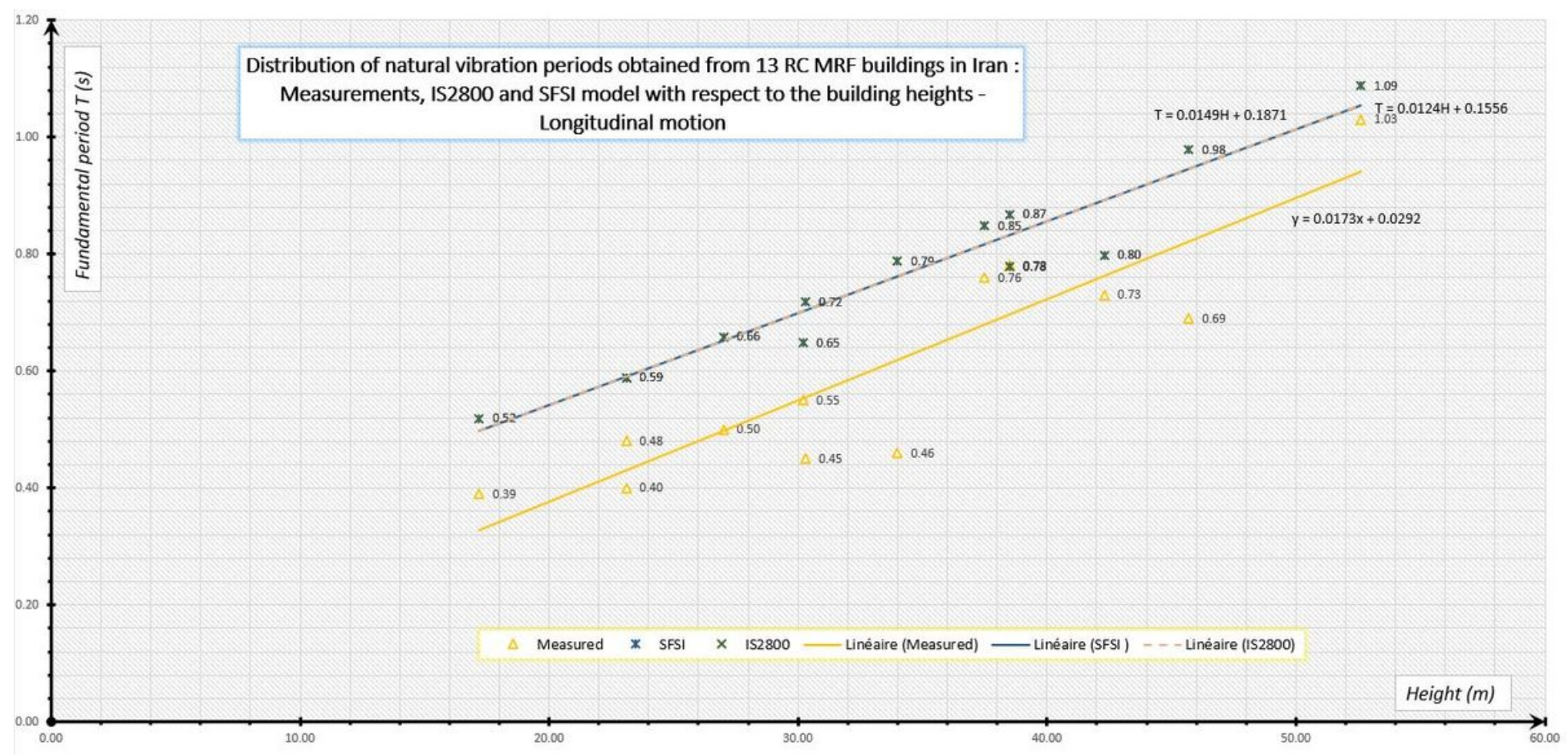

Figure 13

Variation in lateral period value due to change in height from 13 RC MRF buildings in Iran - Longitudinal motion Site II. 


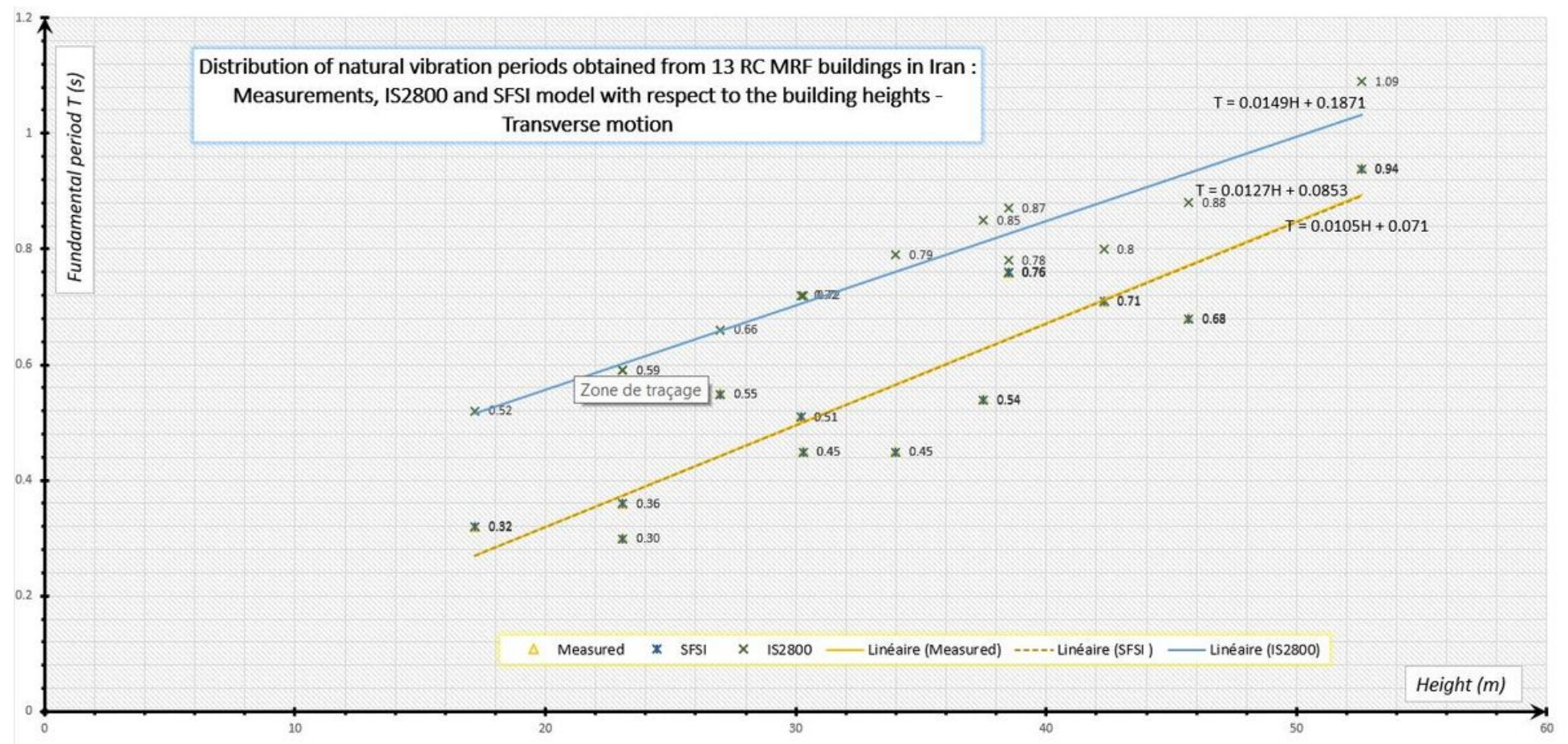

\section{Figure 14}

Variation in lateral period value due to change in height from 13 RC MRF buildings in Iran - Transverse motion Site II.

\section{Supplementary Files}

This is a list of supplementary files associated with this preprint. Click to download.

- GraphicalAbstract.doc 